Article

\title{
Urban Gardening and Green Space Governance: Towards New Collaborative Planning Practices
}

\author{
Sofia Nikolaïdou ${ }^{1, *}$, Tanja Klöti ${ }^{2}$, Simone Tappert ${ }^{2}$ and Matthias Drilling ${ }^{2}$ \\ ${ }^{1}$ Centre of Social Morphology and Social Policy, Department of Social Policy, Panteion University of Social and Political \\ Sciences, 17671 Athens, Greece; E-Mail: so_nikk@hotmail.com \\ ${ }^{2}$ Institute for Social Planning, Organisational Change and Urban Development, School of Social Work, University of \\ Applied Sciences and Arts Northwestern Switzerland, 4053 Basel, Switzerland; E-Mails: tanja.kloeti@fhnw.ch (T.K.), \\ simone.tappert@fhnw.ch (S.T.), matthias.drilling@fhnw.ch (M.D.)
}

* Corresponding author

Submitted: 2 December 2015 | Accepted: 22 January 2016 | Published: 29 February 2016

\begin{abstract}
In the context of urban densification and central urban areas' lack of open spaces, new forms of small-scale urban gardening practices have emerged. These gardening practices respond to urban pressures and open new modes of green space governance, presenting alternative and multifunctional ways to manage and revitalise cities. Focusing on the case of Geneva, the article unfolds two levels of discussion. On the one hand-and with reference to the theorist Habermas-it examines how multiple actors with different interests interplay and cooperate with each other in order to negotiate over open space, while discussing implications for local politics and planning. On the other hand, it describes how these negotiations result in new, innovative, and hybrid forms of public green space. The main findings indicate emerging forms of collaboration, partnerships, and governance patterns that involve public and private sectors and increase participation by civil society actors. Cooperation amongst several interested groups and the collective reinvention of public urban spaces increase these spaces' accessibility for multiple users and actors, as well as present possibilities for alternative and diversified uses and activities. This might underline the hypothesis that future cities will be governed in less formalised ways, and that urban forms will be created through spontaneous, temporary, mobile, and adaptive negotiation processes.
\end{abstract}

\section{Keywords}

collaborative planning; green space governance; hybrid space; open green space; urban gardening

\section{Issue}

This article is part of the issue "Urban Forms and Future Cities", edited by Luca D'Acci (Erasmus University Rotterdam, The Netherlands), Tigran Haas (KTH Royal Institute of Technology, Sweden) and Ronita Bardhan (Indian Institute of Technology Bombay, India).

(C) 2016 by the authors; licensee Cogitatio (Lisbon, Portugal). This article is licensed under a Creative Commons Attribution 4.0 International License (CC BY).

\section{Introduction}

Political and urban restructuring processes since the late 1960s have caused city transformations on different levels (Soja, Morales, \& Wolff, 1983). Concerning the form and fabric of urban settlements, new sociospatial configurations have emerged, framed within the planning paradigm of urban growth and densification. These processes imply a change in planning approach- es and in the meaning of urban open spaces, both of which are seen as highly important for sustainable urban growth (Ward Thompson, 2002). Open space, which embraces both public and private lands, has been intrinsically associated with the 'undeveloped' nature of open pieces of land-vegetated or not (e.g. green spaces, playgrounds, vacant lots, etc.)-and with a regular accessibility to the public. However, traditional open space strategies have generally related to 
publicly owned/managed open space that has been formally laid out for leisure and recreation. In light of new urban configurations and the changing social dynamics of urban space, conceptual and analytic attention has been given to the "access to space as a product of negotiations" (Hackenbroch, 2013, p. 38). On the socio-political level, this characterization of space as a product of negotiations indicates a shift towards collaborative space and land management decisions through civic participation and increased public-private partnerships. Thus, new practices of urban politics treat open space as a ground for diverse uses and forms of coalition amongst several stakeholders, putting it at the core of participatory governance and collaborative planning.

Urban gardening spaces-as one type of open space asset-are considered to promote civic engagement, collective empowerment, and communitybuilding (Glover, 2004; Rosol, 2010; Saldivar-Tanaka \& Krasny, 2004; Tan Leon \& Harvey, 2009). They are also considered productive spaces for sustainable agricultural activities (Drescher, Holmer, \& laquinta, 2006; Pothukuchi \& Kaufman, 1999). Because they combine city and nature, as well as the social and environmental aspects of gardening, urban gardening spaces have become increasingly recognised as productive and socially inclusive uses of open green spaces in cities (Firth, Maye, \& Pearson, 2011; Holland, 2004). Consequently, urban gardening initiatives have been strongly advocated and supported by many public and private actors. Due to a scarcity of space, open green spaces compete with other potential uses of urban space like housing and business zones (Jim, 2004). They are treated as a valuable way to maintain and enable high quality densification of urban settlements, enhancing the attractiveness of the city within the context of increasing city competition. Alternative attempts to facilitate neighbourhood greening and nature within the city have been either temporary (Kulke et al., 2011), or have developed formal and informal green sites in all possible, remaining enclaves within compact areas (Jim, 2004). Further, postmodern lifestyles and "attitudes to nature and sustainability" (Ward Thompson, 2002, p. 59) are generating new and diversified demands for open green space. This suggests that the meaning of open green space is expanding; increasingly, open green space is recognised as central not only to the ecosystem, but also in the amelioration of urban living conditions (Arnberger, 2012), which it does by offering social services, fulfilling psychological needs of citizens (Chiesura, 2004; Germann-Chiari \& Seeland, 2004), and developing and maintaining the quality of life in the city.

\section{Urban Space in Planning Paradigms}

Thus far, urban planning-framed mainly by Rational
Theory-has been oriented towards the conventional, top-down model of comprehensive planning. Its most important function has been "to create a master plan which can guide the deliberations of specialist planners" (Altshuler, 1965, p. 186) and to systematically analyse, predict, and control urban development (Allmendinger, 2009). This rather planner-centric planning model has been widely criticised as rational and objective, anti-democratic, exclusive, and-in the positivist logic of cause and effect-apolitical, and, therefore, as neglecting the influence of society, as well as the values and meanings of the planning process. Moreover, its critics claim that it further disempowers stakeholders and ignores or exacerbates major societal problems, even creating new problems by not taking into account the social consequences of planning (Shannon, 1999).

In order to overcome these problems, emergent planning theories (for an overview, see Allmendinger, 2009; Fainstein \& Campbell, 2012) were expected to become more inclusionary and consensus-based rather than expert-driven (McCann, 2001). The collaborative planning approach is one of these emergent theories, defining planning as an interactive and communicative process in which space utilisation and design issues are negotiated between different stakeholders (Harris, 2002). Its ideas are framed by Habermas' idea of communicative rationality, which seeks to realise objective decisions not through formal rationality, but through communication and agreement between individuals. Therefore, reason can be formed only through the negotiation of equally empowered and fully informed stakeholders in a free and open discourse (Habermas, 1981). Ideally, this negotiation leads to an intersubjective, mutual understanding, also referred to as consensus. Thus, all plans are a result of negotiation about values. Therefore, planning should stem from an open debate that achieves mutual understanding and, if possible, results in consensus (Innes, 1996). This collaborative turn emphasises the political aspects of planning, and sets forward a normative agenda for a more democratic, socially just, and sustainable urban planning. The foremost means to achieve these goals are public participation and deliberation in order to better link the system's logic (e.g. of the planning administration) with citizen's lifeworlds (Healey, 1992).

Collaborative planning originated in a time when society experienced a changing relationship between the state, economy, and civil society. Referred to as the shift from government to governance, political processes, structures, and actors were fundamentally transformed (Heeg \& Rosol, 2007), as seen in the redistribution of political power from the state to private actors. Economic as well as civic stakeholders gained more influence, responsibility, and competency in planning processes (Swyngedouw, Moulaert, \& Rodriguez, 2002) because collaborative planning pictures planning as a collaboration between state, economy, 
and civil society in the management of collective affairs. This development includes a broad opening of planning processes to non-state actors, as well as a turn towards local partnerships; the approach encourages participation of community organisations, local businesses, and residents, and transcends the separation between top-down and bottom-up activities (Elwood, 2002; Ghose, 2005). Therefore, according to Geddes (2006), this local partnership governance presents a new approach to democratic legitimacy and new possibilities for enhancing the capacity of local governance.

However, a critical approach to the so called democratisation of planning addresses the role of neoliberal policies and the repression of the state, which present a number of barriers to and complexities of participation (Elwood, 2002; Ghose, 2005). As Sullivan (2001) and McCann (2001) state, collaborative planning empowers, not only citizens, but also private capital, which often leads to a reproduction of the dominant model of economic development. This also includes the devolution of state responsibilities to citizens (Ghose, 2005), although not "accompanied by a parallel expansion in community organisations' power and influence in urban governance" (Elwood, 2002, p. 123). In this context, the outsourced provision and maintenance of urban green spaces to civil organisations and individuals illustrates how neoliberal policies influence planning processes. As Perkins (2009) shows, these organisations depend heavily on voluntary civic engagement since processes are characterised by state control over resources and reduced planning responsibilities. Furthermore, questions about interests and who controls the planning process are crucial (McCann, 2001) since those in power often reproduce social inequalities in terms of access to and power over spaces, especially when supporting informal and uneven decision-making processes. Although labelled "inclusive planning", collaborative and participative processes are often framed by an expert-driven agenda and their arrangement is pre-set by organising agencies. According to Geddes (2006), informal governance structures may profit civil organisations, but exclude local communities or nonorganised people who lack the necessary resources to participate (Elwood, 2002; Ghose, 2005). In this sense, the informality of the planning process reproduces existing inequalities (Swyngedouw et al., 2002) and seems to undermine democracy, legitimacy, and accountability (Geddes, 2006; Sullivan, 2001).

\section{Urban Gardening in Transforming Cities: Changing Meanings, Hybrid Functions, and New Actors}

Urban gardening is representative of this shift in the meaning and conception of planning practices, as well as the strategic importance of open green space in compact cities. It can be defined as a spatial concept that promotes small-scale open green spaces that are close to or within residential areas and characterised by their multifunctional uses. Its planning process is often determined by collaborations between public and civil society actors.

Two major, complementary issues arise from the emergence of urban gardening within the city, urging us to consider the changing conditions under which urban planning practices take place:

1) New, adaptive, and flexible forms of urban gardening represent a shift in the meaning and function of open green space; these forms create new open green spaces of hybrid character (Nissen, 2008) that are characterised by:

- The temporary nature, flexibility, and adaptability of urban space. Urban gardening initiatives are often installed temporarily "on vacant lots and formerly or future built-up sites" (Fuhrich \& Goderbauer, 2011, p. 53), where they serve recreational purposes and build green corridors, especially in areas with high structural density that lack open green space. They adapt to current spatial developments, represent social demands, and adjust to a site's existing physical conditions and local characteristics. They represent a flexible use of urban space that corresponds to dynamic and multiple activities as well as to the actual needs of the gardeners. Urban gardening initiatives constitute new ways to re-appropriate land through community, collective reactivation, and novel forms of governance (Altés \& Serra, 2012).

- New, multiple functions are recognised and implemented. It is widely acknowledged thatapart from its contribution to food provision, biodiversity, nature, and related ecosystem services within the urban fabric-urban gardening can enhance socially sustainable urban development by supporting local capacity building and providing the possibility for a development that is socially inclusive (Fritsche, Klamt, Rosol, \& Schulz, 2011).

- It creates economic value by contributing to the quality of a city's landscape (its location, scenic setting, built environment, quality of life, recreational value, image, and level of identification) and by qualitatively improving urban areas or upgrading neglected areas. As such, urban gardening initiatives may also influence real estate prices (Lossau \& Winter, 2011). By realising different potential uses in a small area through civil engagement and public accessibility, urban gardens represent a new form of open green space in the city. However, urban gardening initiatives that aim to improve the liveability of an urban area or to upgrade it may also reinforce social inequalities in cities. Although urban gar- 
dening initiatives adopt an environmental ethic, they implement a sustainable planning agenda of urban greening that may result in environmental gentrification, excluding politically and economically vulnerable groups from negotiations on access to urban green spaces (Checker, 2011; Hagerman, 2007). Thus, urban gardening initiatives to make the city greener through collaborative planning approaches may not produce benefits "that are universally enjoyed by all urban inhabitants" (Dooling, 2009, p. 630).

2) Collaborative planning practices in urban gardening projects reflect and enable new forms of urban governance and collaboration. According to Fritsche et al. (2011), slow real estate development or municipality budgetary difficulties open up possibilities for interim, temporary uses and new, collaborative partnerships. Since many urban gardening sites are on land that is not public property, and/or because the state lacks essential resources (such as professional knowhow, time, financial capital, etc.), development of these areas is highly dependent on the resources and engagement of non-state actors. Therefore, instead of state-led planning of urban garden sites, collaborative planning practices that involve various stakeholders in all levels of planning, design, use, and maintenance of the garden site have been applied. Andres (2013) argues that the weaker the planning authorities due to political, financial, or economic crises, the greater the possibilities for non-state actors to-at least temporarily-access and control urban spaces. In such situations, planning processes are more informal and disordered, and power relations are more fluid and complex. In this context, actors follow opportunistic as well as cooperative approaches to achieve their goals.

\section{Research Questions and Method}

This examination of newer urban gardening initiatives in Geneva is embedded in a collaborative planning framework that incorporates negotiation-based interactions among stakeholders with participative forms of governance. Therefore, this research poses the following questions about current gardening practices and their impact on the production and re-appropriation of urban open green space: 1) How do emerging collaborative processes on new urban gardening initiatives affect the negotiation, functions, and governance of green space? 2) How are power and interests distributed amongst the different public and civic participants involved in the process? 3) To what extent are these initiatives linked to Geneva's current planning practices and urban open space policies?
First, a literature review and document analysis were conducted in order to understand the general context of urban development and approaches towards open green spaces in Geneva. A broad definition of documents was applied, ranging from administrative documents (such as legal acts and spatial planning documents) to documents published by or circulated amongst particular gardening initiatives.

Second, to grant an in-depth understanding of current trends, several gardens were visited. For the aim of this small-scale, qualitative research project, the 'Jardins du Centre horticole Beaulieu' was chosen as a case-study representation of two current trends in Genevan urban gardening: municipal and bottom-up initiatives. It depicts new forms of cooperation between civil society, economic, and political-administrative actors, influencing new urban planning and green space governance.

Third, nine semi-structured interviews (and various informal conversations) were conducted with a total of eight interviewees. Of these interviewees, five were public actors who represented the municipality of Geneva (Service of Green Spaces, Unit of Community Action, Service Agenda21 for Sustainable Development, Department of Urban Planning), three represented civil society organisations involved in urban gardening projects (Equiterre, an association for sustainable development; Utopiana, an artistic non-profit organisation), and one represented the Jardins potagers de Beaulieu (Collective Beaulieu/Association les Artichauts). In order to identify initial themes and concepts from the data, as well as move from raw data to evidence-based interpretations, a thematic analysis was conducted. This was undertaken in two stages. The first stage dealt with the management, sorting, and synthesising of the data. The second with systematically interpreting the data in order to move from descriptive to explanatory accounts (Rubin \& Rubin, 2005).

\section{Gardening Initiatives in the City of Geneva: Emerging Forms and Practices}

\subsection{Urban Gardening and Space Scarcity: Changing Forms and Conceptual Shifts}

Ranked amongst the most competitive and economically attractive cities in the world, Geneva is an important city for international organisations and the banking sector. In its highly globalised context, the city seeks to attract not only capital and enterprises, but also new inhabitants. However, despite its abundant employment opportunities, strong migration, and population growth, the housing market's visible failure explains the imbalance in Geneva between the high number of jobs and the relatively low number of flats (Quincerot \& Weil, 2009, pp. 13-15). In the midst of its most acute housing crisis, one of Geneva's top priori- 
ties is the construction of new housing areas, which the city hopes to achieve through urban expansion and 'qualitative densification' of existing, built-up areas. Therefore, its dominant city-planning strategy aims to increase urban density while integrating green spaces into the urban landscape (Quincerot \& Weil, 2009, p. 17). Under these circumstances, new forms of smallscale urban gardening practices have emerged as alternative methods for making dense urban cores greener; these practices have been labelled jardins potagers, plantages, or potagers urbains. Though these terms are not clarified as concepts or in practice, they are widely used to describe many of the urban gardening projects that have been reported in Geneva and neighbouring municipalities. They usually refer to small plots in inner, dense areas, located on private or cityowned land (vacant/unused plots or existing open green spaces) that can be easily and quickly reused.

The Geneva municipality contains around eleven new urban gardening projects; most of these projects have developed within the last 2-3 years (see Figure 1 ). Two main types of jardins potagers should be distinguished: municipal gardens that have developed on the local, neighbourhood scale within the framework of municipal social policies (mainly initiated by the Units for Community Action-UAC), and several bottom-up initiatives that have been widely supported by public action through new forms of participation and cooperation between civil society and political-administrative actors.

Whether as top-down or bottom-up initiatives, they appear to be new and flexible forms of urban gardening, for they respond to the long waiting lists for traditional allotment sites (family gardens) as well to the scarcity of open green space. Their general characteristics can be summarised as followed:

a) small plots in inner areas $\left(6-10 \mathrm{~m}^{2}\right)$

b) on public or private land (vacant/unused plots or existing green/open spaces-lawn front yards, parks etc.)

c) accessible to all people from the surrounding areas (5-10 minutes by foot)

d) allocated without rent or for a small, symbolic participation fee

e) under a generally non-renewable one-two year contract

f) long waiting lists for a plot, selection in order of preference (i.e. proximity to gardening site)

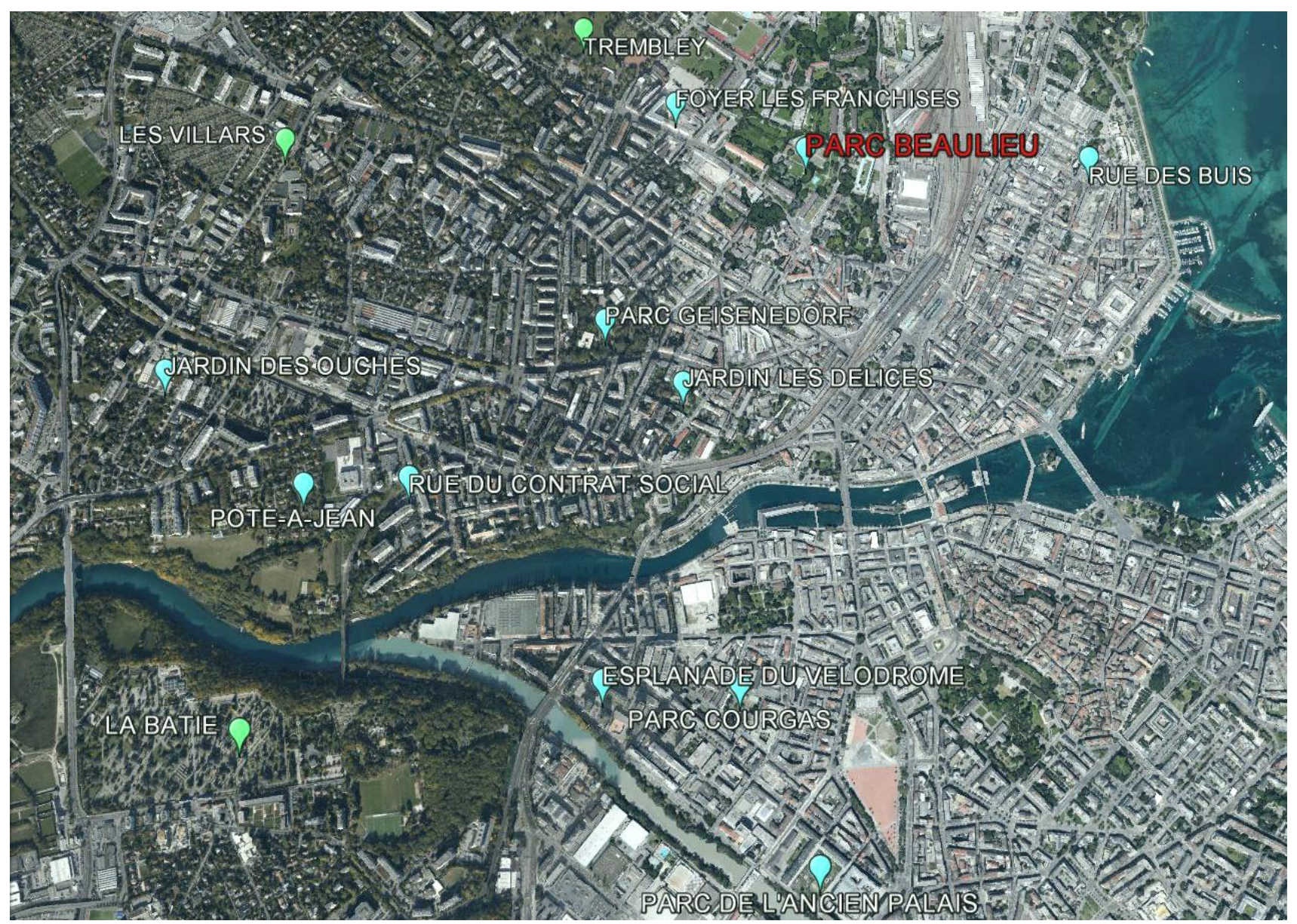

Figure 1. Urban gardening initiatives in the city of Geneva. Source: Google Maps, Nikolaidou, 2014. Green bullet: Family gardens (Jardins familiaux); Blue bullet: New urban gardening projects (Jardins potagers). 


\subsection{Integration in the Local Policy Agenda: Urban Greening and Social Cohesion}

Even though the jardins potagers are not at the centre of the municipal policy agenda, the city supports new forms of urban gardening initiatives, granting the initiatives some political recognition. Though not clearly specified, the term jardin potagers has been introduced more at the cantonal and less at the municipal level through strategic development plans and the policy agenda (Plan Directeur Cantonal 2030, Plan Directeur Communal 2020). Thereby, two main public action priorities, with a particular relevance to new urban gardening trends, can be distinguished. The first can be seen through promotion of the social dimension of public space policy. Perceived as part of the larger concept of social space, potagers urbains are considered part of the general development of collective and reappropriated spaces in the city that aim to foster proximity, social cohesion, and conviviality while also diversifying uses of unused space in the neighbourhood (Canton de Genève, 2013). Situated around housing areas, they may help improve quality of life and enhance urbanite social interaction and cohesion. The second priority is linked to nature and biodiversity. In order to support the city's goal to be a green city, the contemporary concept of "Nature in the city and biodiversity" (Quincerot \& Weil, 2009, p. 175) is being developed in a wider territorial context in which new forms of territories and networks of open spaces unite nature, gardening, and urban development (Daune \& Mongé, 2011). Among other uses, municipalities can use gardening spaces to develop a network of green open spaces through green wedges that penetrate urban core areas (pénétrantes de verdure) (Quincerot \& Weil, 2009). Gardening spaces' multifunctional role of providing corridors for the preservation of nature, agriculture, and recreation in a diversified manner may especially help protect and improve the natural environment; this protection and improvement occurs in the context of increasing inner-city densification.

However, although the Neighbourhood Land Use Plans call for these aspects to be integrated, this intention has not been realized. Apart from the above mentioned strategic orientations at a cantonal level, jardins potagers have not been integrated in the land use plans. They've usually become spaces for negotiation, as well as for temporary and less formalised planning practices. The land is often used on a temporary basis, and projects are created on constructible land. The municipality's approach adapts to citizens' existing demands instead of imposing top-down initiatives. Therefore, the city examines each possible case and creates separate demands for each of them, following opportunistic and short-term strategies to recover unused land. In this context, urban gardening is conceived as a low-cost way to reactivate and maintain unused space in a way that carries a low risk of failure and can also be seen as an ad hoc 'upcycling' process of space (a reuse of the space by adding new value).

\subsection{Increasing Collaborative Processes in the Negotiation of Space}

The city of Geneva aims to increase citizen participation and collaborative planning in different forms and on various spatial levels. With its so called contrats de quartiers (district contracts), the city has implemented new forms of governance through stronger collaboration with civil organisations in order to meet the needs of its inhabitants (Quincerot \& Weil, 2009). In the case of urban gardening, local partnerships and new collaborations have been developed in order to negotiate open space and increase participation. Such collaborative processes can involve public actors from different services in municipal administration, as well as non-state actors like non-profit associations, grassroots movements, and other civil society representatives or private actors.

The City of Geneva usually structures public involvement in urban gardening projects through the different units and services of municipal administration: Units for Community Action that are mainly in charge of municipal gardens (UAC-Unité d'Action Communautaire, Département de la Cohésion Sociale), Service of Green Spaces (SEVE-Service des espaces verts, Département de l'environnement urbain et de la sécurité), Service Agenda 21-Sustainable City (Ville Durable), and Municipal Property management (Gérance immobilière municipal) of the Department of Finance and Housing (Département des finances et $d u$ logement). In addition, the municipality seeks external help to implement urban gardening initiatives; nonprofit organisations are becoming major channels for the development of participative urban gardening projects. They advise and support the municipality in developing and actively promoting urban gardening projects. This feeds directly into the municipal approach of adapting to the existing demands of citizens by embracing a participatory approach. Future users are encouraged to rethink their roles in a co-modified collective space and to establish a cooperative structure among users; while the municipality makes use of the knowledge and expertise of non-profit organisations. The range of stakeholders and the roles these stakeholders play in the negotiation of space are shown in a three-stage collaborative process (see Figure 2).

Nevertheless, in a context of space scarcity, where access to land is most important, the negotiation of space and governance patterns often takes place through informal processes. According to the municipal administration, there is an infinite potential to support urban gardening projects in the inner-city area because land can be made available by re-activating and maintaining unused space (front yards of block of flats, parks, 


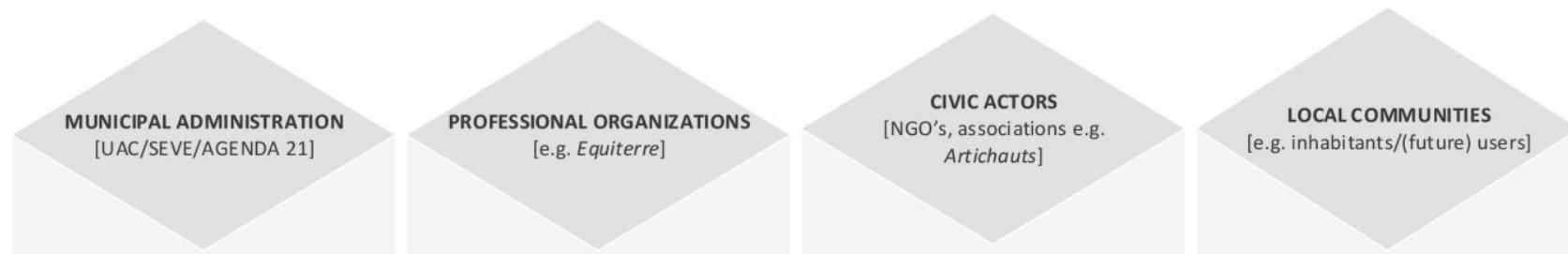

PREPARATION STAGE / NEGOTIATION PROCESS

Designation of the site and securing land access

As the owner of the site the city is addressed by private initiators to give access to the land. If the site lies on private ground the municipality mediates between land owners and project initiators.
They intermediate both with municipal and private actors as well as interested users in order to promote urban gardening initiatives.
They address the land owner to get access to the land to realize their private initiatives.
They reclaim the land for urban gardening.

\section{Planning of structure, functions and design of the site}

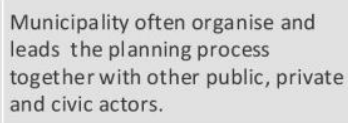

Due to their specific resources and know-how they are engaged to implement or support the planning process. They coordinate the activities of the different actors.
They negotiate their plans with the municipal administration/land owner in order to find a formal/ informal agreement.
Future users are invited to bring in own suggestions into the planning process.

\section{IMPLEMENTATION STAGE}

\section{Building the site / Enhancing civil collaborative processes}

The municipality supports the implementation (infrastructure \& technical support) of the plans directly or by engaging professional organizations.

\author{
They are engaged to realize the \\ project and coordinate the \\ activities of the different actors.
}

They invest their own resources to realize the project, often supported by municipal engagement.
Future users are invited to take part in building the urban garden.

\section{FOLLOW UP AND CONSOLIDATION STAGE}

\section{Using and maintaining the site}

Some of the urban gardens are maintained by administrative departments (SEVE, UAC), others by private organizations.
Usually they are not involved at this stage.
Civic actors are responsible for the maintenance of the garden site according to the agreement.
Users are involved in daily tasks of maintenance and are responsible to comply with the collective rules of the site (spaces of collective responsibility).

Figure 2. The different collaborative processes in urban gardening and negotiation of space in Geneva: Building consensus among actors. Source: Authors.

and vacant land). However, no accurate policy document or inventory of vacant land sets out the potential land available for urban gardening. Existing documents managed by the municipal property service (Gérance immobilière) do not point out the overall possibilities for open green space; there is a wide variety of unused land. For example, front yards of private buildings may be vacant land that has not necessarily been registered. Therefore, the city examines each possible case and demand for urban gardening separately and rather haphazardly, following opportunistic and short-term strategies that align with densification strategies.

Thus, urban gardening initiatives are considered flexible and barely formalised forms that adapt to the lack of open green space in the dense urban core with a more temporal land-use dimension. New projects are often created on land that is classified as constructible, but is still undeveloped. The land might be informally classified as agricultural in order to create short-term urban gardens (2-3 years), but also be constructible until used for residential or other urban projects. Some urban gardening projects are not based on contracts. Instead, deals are based on mutual trust between users and land owners for the municipal services (contracts of confidence with private owners, NGOs, and/or municipalities as intermediates to guarantee that there will be no conflicts-i.e. in regards to noise, dirt, a healthy and safe living environment, etc.). The municipality gives priority to the front yards of flats (pelouses) and unused urban spaces rather than parks or other green areas that already have a public use. Though 
land can be either private or public (municipal), front yards are mainly privately owned, which complicates negotiation processes; attempts to reach a contract of confidence become time-consuming. Here, the municipality mediates to facilitate negotiation processes and guarantee the safe use of the space. Urban gardening is considered a short-term and low-cost land management approach that optimises vacant land use through production and greening and reduces the risk of failure.

\section{The Case of 'Jardins Potagers de Beaulieu': Emerging Public and Civic Partnerships and Hybrid Forms of Green Space Governance}

\subsection{Food Re-Localisation and Social Connectivity}

The Beaulieu project is situated in the former horticultural centre of the Municipal Service of Green Spaces, which was transformed into an urban gardening site after the Municipal Service of Green Spaces moved its operations to another area. Located in a central and densely populated residential district (between the districts of Cropettes and Grand Pré), the site has a total surface of approximately $9,300 \mathrm{~m}^{2}$, and is part of a greater park that extends over $65,300 \mathrm{~m}^{2}$ of land (Ville de Genève, 1993).

This particular case is illustrative because it combines two different types of urban gardening initiatives, involving multiple users and actors from the municipality and civil society/business who collaborated to resurrect the abandoned public land and its existing resources for urban gardening. More specifically, some of Beaulieu's abandoned, ground-level beds and greenhouses have been allocated to citizens who participate in a Municipal garden initiative, as well as to several associations and external users-like schools-that take part in the Collective Beaulieu (see Figure 3).

Municipal gardens are developed under the authority of the Units for Community Action UAC and the framework of neighbourhood-oriented social policies. This type of garden, also called citizens' gardens (potagers citoyens), is open to all inhabitants of the district who are interested in applying for a plot. All users have

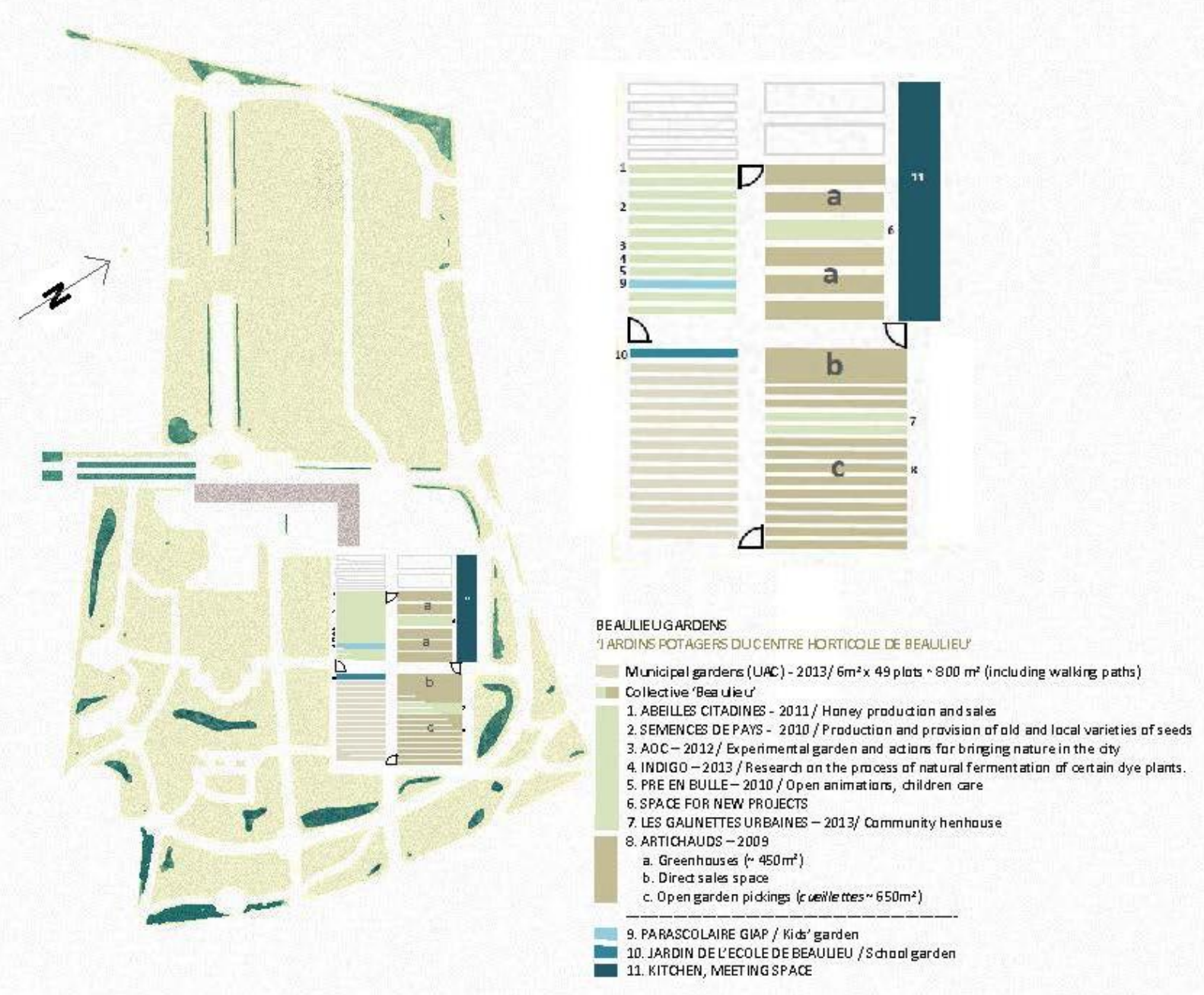

Figure 3. The Beaulieu Gardens: Multiple actors and functions. Source: Nikolaidou, 2014 (based on a map image layer of the park, Ville de Genève, 1993, p. 27). 
their own plot (49 parcels of $6 \mathrm{~m}^{2}$ in a total of $800 \mathrm{~m}^{2}$ including pathways), receive all the necessary water, tools, and support to start and maintain their garden. Plots are allocated only to neighbourhood residentsthose who live within a close distance-under a nonrenewable contract for two years. Residents pay no rent, only a reimbursable participation fee that guards against any damages that may occur in the garden. The plots have no fencing, and can be used by an individual, a family, or shared between more than one person. The UAC is responsible for the operation and surveillance of the site. According to UAC representatives, the gardens are highly diversified in terms of the social mixture of caretakers (e.g. high, middle, and lowincome residents, multi-ethnic, intergenerational etc.). The UAC's main aims are 'strengthening community life and creating a social space for interaction, contact and creativity for the inhabitants of the nearby neighbourhoods' (Interviews with Municipal Service UAC) through the gardens. The project's growing popularity has created a long waiting list; approximately 200 residents wish to join Beaulieu gardens.

Gardens run by bottom-up initiatives combine educational, food-activist, and market-oriented activities towards Community Supported Agriculture (CSA or ACP-Agriculture Contractuelle de Proximité) and short food chain networks. These initiatives are currently represented by the Collective Beaulieu and one school (School of Beaulieu). The Association Artichauts, the most important actor in Beaulieu, occupies the largest amount of land, including greenhouses and hotbeds. The association produces certified organic plants (200,000 seedlings per year), which are sold to 9-10 bigger farms and cooperatives in the agglomeration. All of their clients are working with CSA bio baskets, which are delivered to urban dwellers. At the same time, Artichauts provide local, organic, fresh vegetables on the local neighbourhood-scale through open garden pickings. During the sale, all residents and passers-by are welcome to collect vegetables straight from the plant, weigh them, and leave payment in a box. The garden also serves as a green meeting space, which hosts several activities and neighbourhood events and supplies gardening information and materials. The association Artichauts, together with Pré en Bulle, works regularly with schools and community centres to put on educational events that enhance public awareness, knowledge, and participation in nature conservation.

\subsection{Negotiation Process, Space, and Governance Patterns: The Power of Informality}

Since the relocation in 2008 of the Beaulieu horticultural site of SEVE to another area, and shortly after the evacuation of the site, several civil-society actors involved themselves in the area's re-vitalisation, all claiming the empty and unused space to perform their activities. In 2009, SEVE (which manages the former horticultural centre) allocated Artichauts some of the site's old greenhouses in response to the non-profit's request for space in which to grow plants. Shortly thereafter-in 2010-Artichauts and Pré en bulle, in cooperation with other cooperatives, co-founded the Collective Beaulieu without official direction from the municipal authorities. In the context of anticipated renovations of the abandoned park, this group proposed to the municipality a collaborative project that would aim to foster urban garden development and related diversified activities in the former horticultural centre.

Though the municipality initially reacted with disbelief and scepticism, the project was fated to succeed. Municipal support was finally obtained in 2010, primarily because the general public seemed to favor the Collective's proposal because it would enrich the surrounding neighbourhoods. Using the existing infrastructure, the project aimed to provide a green and versatile space for neighbourhood residents, integrate relations with nature, and meet the needs of sustainable local food production by promoting proximity farming activities and food sovereignty (Collectif Beaulieu, 2010; Pré en Bulle, 2008). SEVE and UAC were the two major municipal actors that actively supported the establishment of urban gardening in the Beaulieu Park, which they demonstrated by contributing financially. SEVE embraced the idea because the "proposed activities were consistent with the goals of preserving the agricultural history and the horticultural heritage (greenhouses) of the Park Beaulieu. At the same time it was considered as a way to penetrate greenery in the urban fabric" (Interview with SEVE). Likewise, according to UAC, the proposal was compatible with the municipal community gardens that already existed nearby, and could "steer a society's demand for urban gardening by improving the quality of life of the surrounding neighbourhood". Therefore, after a slow decision-making process, the UAC municipal garden was integrated into the site in 2013.

Beaulieu depicts new forms of space governance through collaboration and partnerships between public and private actors. Examining the Beaulieu negotiation process, several characteristics of planning through debate (Healey, 1992) can be revealed. The involved actors have different perceptions of proximity and different motivations about urban agriculture and urban gardening; they also have different organisational and governance models. On the one hand, the municipality seeks proximity with citizens and to promote social contact and cohesion. On the other, associations in Beaulieu are linked with proximity agriculture networks, community-supported agriculture farms, cooperatives, and customers. Though driven from different conceptions of locality and proximity, experience shows that both initiatives (Collective Beaulieu and the UAC gardens) can be successfully related, and that 
both parties can agree on a collective vision about sharing a common space. From a perspective of communicative rationality (Habermas, 1981), the actors established a mutual understanding about how to use the site; they promoted the normative ideas of sustainable production, protection of nature, and social cohesion as a consensual ground for their various actions. Thus, Beaulieu is a place where multiple and diverse user groups with compatible and complementary uses coexist, reclaim, co-modify, and revive an abandoned horticultural centre by installing various gardening projects and creating community space. It shows that mobilising various non-state stakeholders with the support of public authorities can produce a successful combinationsuccessful in the sense of linking the logic of the planning administration with the lifeworlds of activists, as well as surrounding neighbourhood (Healey, 1992).

The deliberative approach adapted in the Beaulieu case is embedded in a governance mode of collaboration: though primarily derived as a bottom-up initiative, the strong inter-dependence between public and civic actors questions the dichotomy between bottomup and top-down approaches. It allows the utilisation of the different potentialities and capabilities of various stakeholders (Elwood, 2002; Ghose, 2005). In this sense, Beaulieu may be characterised not as a struggle between the 'ones above and the others below', but rather as a collaboration between state, economy, and civil society in the management of their collective affairs. However, both parties depend on each other: the Collective Beaulieu's cooperation with public actors, under the active support of municipal administrative actors, is a win-win situation-the project would likely have failed without this synergy. But when this synergy is added to the already existing monetary connections between the Collective and the municipality (Ernwein, 2014), the Collective and its associations clearly cannot be pictured as financially autonomous. This means that the Collective relies on municipal support, which might jeopardise (or marginalise) Collective members' roles and interests in the decision-making process. On the other hand, the municipality's negotiations must end in mutual benefit in order for the municipality to make use of public land. Therefore, this project is also a way "to maintain and manage the communal land with minimal cost" (interview with SEVE). In other words, the local partnership governance (Geddes, 2006) allows the state to prove its democratic legitimacy and its capacity for administrative control in a context of urban challenges (Quincerot \& Weil, 2009). However, the municipality collaborates via informal processes that are based on mutual commitment rather than on official contracts. The administration of garden operations typically requires the SEVE to partner with local community groups, giving them permission to access the land. These informal contracts of confidence reveal an alternative governing structure that links several ac- tors, interests, and perspectives through multi-actor decision-making.

As many critiques of Habermas' communicative theory have stated, there is no such thing as a discourse that is free of power (Flyvbjerg, 1998). Therefore, the result of the deliberative process in Beaulieu must be considered the outcome of power struggles. The Collective Beaulieu substantially widened its influence, responsibility, and competencies through the process, and was able to claim the status of a powerful actor. Contrarily, the other gardeners cannot exercise power, neither through debate nor structure. The restriction of gardeners' contracts to two years creates a constant flux of gardeners; additionally, gardeners' interests are not organised, but only represented by UAC. While access to the site is widely distributed to all Genevan residents, actors with institutional, personal, and financial capital have exclusive power over the space.

\subsection{The Shifted Meanings and Functions of Open/Green Space}

As discussed in the theoretical part of this article, new forms of urban gardening can mainly be described within the framework of re-using and re-appropriating open green space and vacant land. These new, adaptive, and flexible forms of green space governance represent a shift in the meanings and functions of urban open green space, presenting new possibilities for urban development. In a compact urban context that lacks open spaces, green spaces can be re-configured and readjusted to serve multiple and diversified uses while the size and location of urban gardens are debated. The temporariness, flexibility, and adaptability that characterise these emerging garden types contribute to the formation of the hybrid character of open spaces. This hybridisation of space opens the accessibility and usability of public resources (Nissen, 2008) to a variety of new uses and users, as well as the interactions between them. Based on the Beaulieu example, we've noticed that a formerly derelict public green space to which persons have limited access, such as the Beaulieu's empty horticultural centre prior to creation of the collective gardens, can be transformed from a single-use (horticultural and nursery production) and single-actor space (SEVE managed the space) to a free-access, multi-user, multi-actor, and multi-functional space.

Since they have different perceptions, interests, and motivations, the various actors involved use different terms for urban gardening. Thus, the negotiation of space is also a negotiation of the space's meaning. Notwithstanding the differences and sometimes the divergence of views among actors and users, the gardening space displays complementary perceptions of urban gardening's role and its multiple functions. By combining social, economic, and ecological aspects with alternative agri-food networks, this public garden- 
ing space represents the diversified role of a shared public space (see Figure 4). Through the threefold interest that was realised in Beaulieu (ecological, social, and economic), an agenda of sustainable and integrated development can be identified. This hegemonic discourse of urban development frames the activities on site while excluding those ideas that do not suit the dominant agenda. The common perception that Beaulieu, a formerly derelict horticultural site, has been transformed into a sustainable project of urban development must therefore be challenged, particularly through concerns of environmental gentrification. We should ask the questions, "What could have been done instead of the actualized garden project (e.g. an autonomous youth centre, allotment garden site, or an industrial use-or even no use at all), and who is allowed to access the urban space or has been excluded through informal negotiation processes on urban green space (Checker, 2011; Dooling, 2009)?"

\section{Conclusion}

The research shows that current trends in urban gardening initiatives reflect a shift in the terms and con- cepts of emerging forms of urban gardening. As a consequence of evolving social conditions and urban restructuring processes (densification), changing and more adaptive forms of urban gardening are emerging through the use (re-use) of remnant or derelict public spaces at the local neighbourhood level. Thus, spacious forms of urban gardening are not supported, giving rise to small-scale, more flexible, informal, and adaptive forms. These initiatives spring from the city's broader efforts to improve sustainability and social inclusion in neighbourhoods through green space governance.

The main findings show that weaknesses can be found mainly in the long-term viability of the projects and their integration in planning practices. Although the Genevan city administration supports these initiatives and broad collaborations with bottom-up actors, there exists no clear, specific strategy or overall plan to promote urban gardening through concrete policies or explicit regulations. Apart from some strategic orientations, a long-term vision for these initiatives could be seriously obstructed by reluctance to designate urban gardening as a special land use in zoning plans and other planning documents. Thus, these initiatives are small-scale, sporadic projects that involve informal

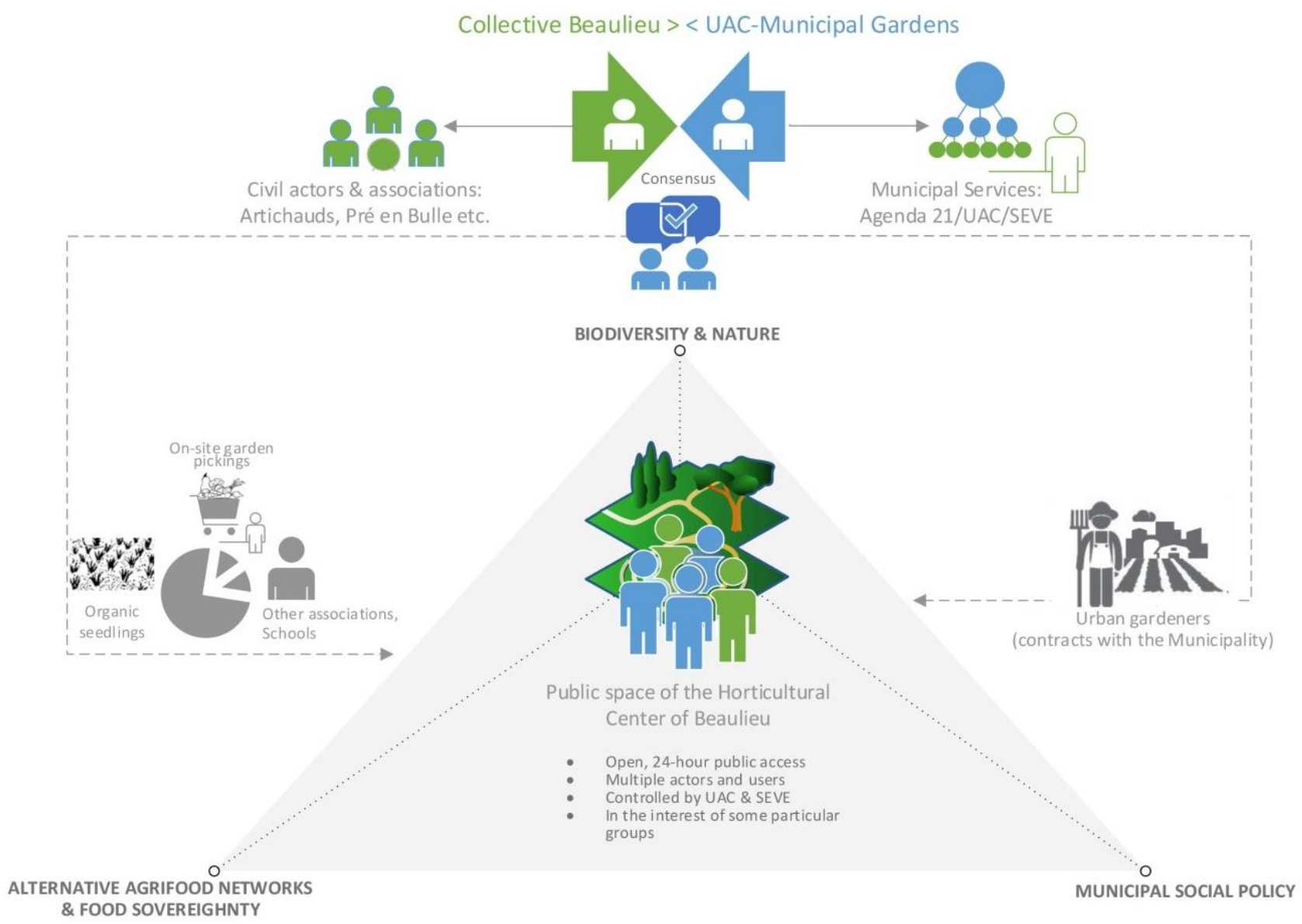

Figure 4. The Beaulieu example for new collaborative planning practices and the creation of hybrid forms of public space. Source: Authors. 
practices of negotiation and access to land. Urban gardening appropriately depends on urban density, and adapts to a given situation of low land availability and slow real-estate development; it is also a quick way to re-activate public space. At the same, as short-term land management practices, urban gardening preserves the attractiveness of vacant land for any kind of future real estate or alternative development while impeding a long-term use of space for food-growing. Therefore, urban gardens provide the means to adaptively reuse temporary open/green space as long as they can be removed for future development of the land.

Whether as top-down, bottom-up, or mixed initiatives, regulated or less formalised, these new forms of urban gardening depict new forms of participation and cooperation between civil society and politicaladministrative actors in urban governance. Beaulieu provides a vivid example of an innovative and alternative area of experimentation that has created hybrid forms of urban gardening and green space governance. New socio-economic functions and transactions take place under emerging collaborative governance structures and changing planning practices. It offers the possibilities of synergies, exchange platforms, and meeting spaces when occasional on-site product collection and sales are permitted-an active way to gather surrounding residents and engage them in participation. It presents a new, multifunctional way to manage and revitalise vacant open space while still giving citizens-through a consensus-orientated approach to urban planning and governance-the right to re-use the public space.

In one way, through their more informal and ad hoc negotiation processes, these gardens represent a new form of citizen participation and a less actively engaged public sector. From a governance perspective, the distinction between top-down and bottom-up approaches is not a suitable one; practices must be conceived as a two-way collaborative process. However, although the municipalities aim to strengthen citizens' involvement and responsibility by allowing them to access land and by granting diversified activities to multiple users, they maintain a certain degree of municipal control in the decision-making process. Therefore, two contradictory trends emerge: the governance of urban space is characterised by less state responsibility and activity. The space is no longer fully managed by the municipality, yet it is still controlled by a range of municipal services. In this way, the municipality presents the possibility of interim, temporary uses; citizen participation; and grassroot involvement "quick and non-bureaucratically" (Kulke et al., 2011, p. 222). It builds a consensus and a winwin situation for all stakeholders, but still regulates/controls the (temporary) use of vacant spaces. Besides, the temporary nature of these initiatives may be exclusive and provide short-term benefits for a few people instead of long-term outcomes for society.
Therefore, rather than insisting on the dualism of either top-down or bottom-up strategies, a special significance should be placed on how new modes of open space governance on new urban gardening initiatives depend on informal collaboration amongst different actors. This means that the governance debate should take into account inherent power relations between different actors when negotiating governance principles.

Even in the absence of prolonged planning procedures, these changing forms of urban gardening initiatives can influence future landscapes and synergies; they may be a promising area for cooperation on the local and policy level. They merge the social and environmental aspirations of several users and stakeholders with new forms of green or innovative, temporary use of the land. Yet the economic perspective on market-oriented possibilities for the site should not be underestimated; special attention should be given to food security aspects of the initiative that are associated with alternative, local food distribution networks. Cooperation amongst interested groups and collective reinvention of public urban space can increase the space's accessibility to multiple users and actors, as well as its alternative uses, activities, and perspectives. Collective practices that stimulate the use of public and private space should be encouraged so that urban environmental management may be enhanced and so that a more permanent and sustainable use of vacant lots may be facilitated. It is a question for further research how sustainable, new forms of urban gardening can influence policies at the local and national level, and whether these new governing structures are central in shifting new urban gardening and urban agriculture paradigms in urban planning paradigms.

\section{Acknowledgments}

This article is based on original fieldwork that was conducted by Sofia Nikolaidou during a short term scientific mission, partially funded by a STSM Grant from the COST Office (COST Action-TU 1202: Allotment Gardens in European Cities). Supported by the Institute for Social Planning in Basel (University of Applied Sciences and Arts, Northwestern Switzerland), the overall research is part of the project within the COST-Action entitled, "Future Scenarios of Allotment Gardens in the context of increasing urban densification and urban open space policies", which is financed by the State Secretariat for Education, Research and Innovation SERI. The authors would also like to thank all the people who were interviewed in the field and the anonymous referees who provided constructive comments that improved the manuscript.

\section{Conflict of Interests}

The authors declare no conflict of interests. 


\section{References}

Allmendinger, P. (2009). Planning theory (2nd ed.). Houndsmill and New York: Palgrave Macmillan.

Altés, A., \& Serra, M. (2012). Latent spaces in the city: Hybrid practices in the urban realm. In D. Babalis (Ed.), Chronocity: Sensitive interventions in historic environment (pp. 24-26). Firenze, Italy: Alinea editrice, s.r.l.

Altshuler A. (1965). The goals of comprehensive planning. Journal of the American Institute of Planners, 31(3), 186-195.

Andres, L. (2013). Differential spaces, power hierarchy and collaborative planning: A critique of the role of temporary uses in shaping and making places. Urban Studies, 50(4), 759-775.

Arnberger, A. (2012). Urban densification and recreational quality of public urban green spaces: A Viennese case study. Sustainability, 4(4), 703-720.

Canton de Genève. (2013). Plan directeur cantonal 2030. A14: Promouvoir de nouvelles formes de jardins familiaux et encourager la création de plantages. Geneva, Switzerland: République et Canton de Genève.

Checker, M. (2011). Wiped out by the "greenwave": Environmental gentrification and the paradoxical politics of urban sustainability. City \& Society, 23(2), 210229.

Chiesura, A. (2004). The role of urban parks for the sustainable city. Landscape and Urban Planning, 68(1), 129-138.

Collectif Beaulieu. (2010). Projet Beaulieu. Retrieved from www.preenbulle.ch/files/projet_collectif_beau lieu_2010.pdf

Daune, L., \& Mongé, N. (2011). L'agriculture urbaine, un fondement dans le projet de territoire. Urbia-Les Cahiers du développement urbain durable, 12, 85106.

Dooling, S. (2009). Ecological gentrification: A research agenda exploring justice in the city. International Journal of Urban and Regional Research, 33(3), 621639.

Drescher, A., Holmer, R., \& laquinta, D. (2006). Urban homegardens and allotment gardens for sustainable livelihoods: Management strategies and institutional environments. In B. M. Kumar \& P. K. R. Nair (Eds.), Tropical homegardens: A time-tested example of sustainable agroforestry (pp. 317-338). Dordrecht, The Netherlands: Springer.

Elwood, S. (2002). Neighborhood revitalisation through 'collaboration': Assessing the implications of neoliberal urban policy at the grassroots. GeoJournal, 58, 121-130.

Ernwein, M. (2014). Framing urban gardening and agriculture: On space, scale and the public. Geoforum, 56, 77-86.

Fainstein, S., \& Campbell, S. (2012). Introduction: The structure and debates of planning theory. In S. Fain- stein \& S. Campbell (Eds.), Readings in planning theory (pp. 1-20). West Sussex: Wiley-Blackwell.

Firth, C., Maye, D., \& Pearson, D. (2011). Developing "community" in community gardens. Local Environment, 16(6), 555-568.

Flyvbjerg, B. (1998). Rationality and power: Democracy in practice. Chicago: University of Chicago Press.

Fritsche, M., Klamt, M., Rosol, M., \& Schulz, M. (2011). Social dimensions of urban restructuring: Urban gardening, residents' participation, gardening exhibitions. In W. Endlicher, P. Hostert, I. Kowarik, E. Kulke, J. Lossau, J. Marzlff, E. Van der merr ... G. Wessolek (Eds.), Perspectives in urban ecology (pp. 261-296). London: Springer.

Fuhrich, M., \& Goderbauer, E. (2011). Urban restructuring: Making 'more' from 'less'. In B. Müller (Ed.), Urban regional resilience: How do cities and regions deal with change (pp. 49-58). Berlin: Springer.

Geddes, M. (2006). Partnership and the limits to local governance in England: Institutionalist analysis and neoliberalism. International Journal of Urban and Regional Research, 30(1), 76-97.

Germann-Chiari, C., \& Seeland, K. (2004). Are urban green spaces optimally distributed to act as places for social integration? Results of a geographical information system (GIS) approach for urban forestry research. Forest Policy and Economics, 6(1), 3-13.

Ghose, R. (2005). The complexities of citizen participation through collaborative governance. Space and Polity, 9(1), 61-75.

Glover, T. (2004). Social capital in the lived experiences of community gardeners. Leisure Sciences, 26(2), 143-162.

Habermas, J. (1981). Theorie des kommunikativen handelns. Frankfurt: Suhrkamp Verlag.

Hagerman, C. (2007). Shaping neighbourhoods and nature: Urban political ecologies of urban waterfront transformations in Portland, Oregon. Cities, 24(4), 285-297.

Harris, N. (2002). Collaborative planning: From theoretical foundations to practice forms. In P. Allmendinger M. \& Tewdwr-Jones (Eds.), Planning futures: New directions in planning theory (pp. 21-43). London: Taylor \& Francis.

Hackenbroch, K. (2013). Negotiating public space for livelihoods: About risks, uncertainty and power in the urban poor's everyday life. Erdkunde, 67(1), 37-47.

Healey, P. (1992). Planning through debate: The communicative turn in planning theory. The Town Planning Review, 63(2), 143-162.

Heeg, S., \& Rosol, M. (2007). Neoliberale Stadtpolitik im globalen Kontext. Ein Überblick. Prokla: Zeitschrift für kritische Sozialwissenschaft, 37(4), 491-509.

Holland, L. (2004). Diversity and connections in community gardens: A contribution to local sustainability. Local Environment, 9(3), 285-305.

Innes, J. E. (1996). Planning through consensus building: 
A new view of the comprehensive planning ideal. Journal of the American Planning Association, 62(4), 460-472.

Jim, C. Y. (2004). Green-space preservation and allocation for sustainable greening of compact cities. Cities, 21(4), 311-320.

Kulke, E., Brammer, M., Otto, B., Baer, D., Weiß, J., \& Zakirova, B. (2011). Urban economy. In W. Endlicher, P. Hostert, I. Kowarik, E. Kulke, J. Lossau, J. Marzlff, E. Van der merr... G. Wessolek (Eds.), Perspectives in urban ecology. Studies of ecosystems and interaction between humans and nature in the metropolis of Berlin (pp. 196-230). London: Springer.

Lossau, J., \& Winter, K. (2011). The Social construction of city nature: Exploring temporary uses of open green space in Berlin. In W. Endlicher, P. Hostert, I. Kowarik, E. Kulke, J. Lossau, J. Marzlff, E. Van der merr . . . G. Wessolek (Eds.), Perspectives in urban ecology. Studies of ecosystems and interaction between humans and nature in the metropolis of Berlin (pp. 333346). London: Springer.

McCann, E. J. (2001). Collaborative visioning of urban planning as therapy? The politics of public-private policy making. Professional Geographer, 53(2), 207218.

Nikolaidou, S. (2014). Emerging forms of urban gardening in Geneva (STSM Report). Basel, Switzerland: Urban Allotment Gardens. Retrieved from www.urban allotments.eu/fileadmin/uag/media/STSM/STSMRep ort_SN.pdf

Nissen, S. (2008). Urban transformation from public and private space to spaces of hybrid character. Sociologickyčasopis, 44(6), 1129-1149.

Perkins, H. A. (2009). Out from the (green) shadow? Neoliberal hegemony through the market logic of shared urban environmental governance. Political Geography, 28(7), 395-405.

Pothukuchi, K., \& Kaufman, J. L. (1999). Placing the food system on the urban agenda: The role of municipal institutions in food systems planning. Agriculture and Human Values, 16, 213-224.
Pré en Bulle. (2008). Projets enfants: Volet 2 du projet Beaulieu. Geneva: Pré en Bulle. Retrieved from www.preenbulle.ch

Quincerot, R., \& Weil, M. (2009). Genève 2020: Plan directeur communal de la Ville de Genève. Genève: Ville de Genève.

Rosol, M. (2010). Public participation in post-Fordist urban green space governance: The case of community gardens in Berlin. International Journal of Urban and Regional Research, 34(3), 548-563.

Rubin, H. J., \& Rubin, I. S. (2005). Qualitative interviewing: The art of hearing data. London: Sage.

Saldivar-Tanaka, L., \& Krasny, M. (2004). Culturing community development, neighborhood open space, and civic agriculture: The case of Latino community gardens in New York City. Agriculture and Human Values, 21, 399-412.

Shannon, M. A. (1999). Moving from the limits and problems of rational planning toward a collaborative and participatory planning approach. In P. Glück, G. Oesten, H. Schanz, \& K. R. Volz (Eds.), EFI Proceedings 30: Formulation and implementation of national forest programmes (pp. 139-151). Finland: European Forest Institute.

Soja, E., Morales, R., \& Wolff, G. (1983). Urban restructuring: An analysis of social and spatial change in Los Angeles. Economic Geography, 59(2), 195-230.

Sullivan, H. (2001). Modernisation, democratisation and community governance. Local Government Studies, 27(3), 1-24.

Swyngedouw, E., Moulaert, F., \& Rodriguez, A. (2002). Neoliberal urbanisation in Europe: Large-scale urban development projects and the new urban policy. Antipode, 34(3), 542-577.

Tan, L. H. H., \& Harvey, N. (2009). "Community in bloom": local participation of community gardens in urban Singapore. Local Environment, 14(6), 529-539.

Ville de Genève. (1993). Les parcs de Genève. 125 ans d'histoire. Genève: SEVE.

Ward Thompson, C. (2002). Urban open space in the 21st century. Landscape and Urban Planning, 60, 59-72.

\section{About the Authors}

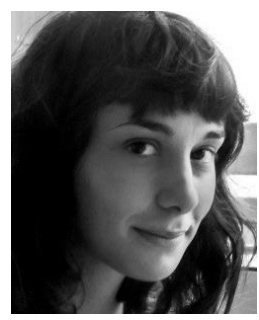

\section{Dr. Sofia Nikolaidou}

Sofia Nikolaidou is an urban and regional planner and research associate at the Centre of Social Morphology and Social Policy (Panteion University). She received her PhD in 2012 from the School of Architecture, Department of Urban and Regional Planning (National Technical University of Athens). Her research and teaching topics cover spatial planning and new approaches to sustainable urban development, with particular focus on urban sprawl, urban-rural relationships, local development, and green space governance. 


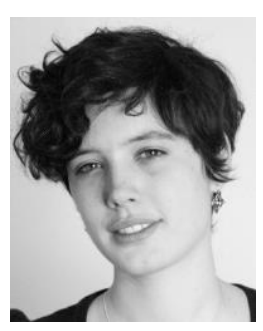

\section{Tanja Klöti}

Tanja Klöti studied at the University of Fribourg (Switzerland), and concluded 2014 with a Masters in Social Sciences. Currently, she is employed at the Institute for Social Planning, Organizational Change and Urban Development as a junior researcher and teacher. Her research focus lies in social urban development, participative urban planning, and urban spatial policy.

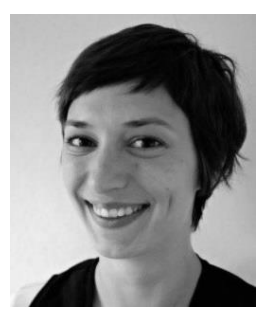

\section{Simone Tappert}

Simone Tappert holds a master degree in Social and Cultural Anthropology (University of Vienna) and Applied Social Research (Trinity College Dublin). Since 2012 she has worked as a researcher at the University of Applied Sciences Northwestern Switzerland in the field of social planning and urban development. Her research interest is in urban and social planning in European cities, with a particular interest in gender and qualitative research methods.

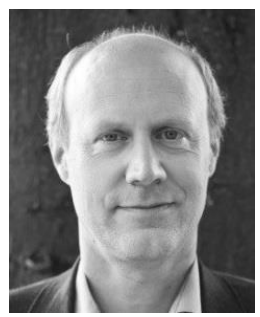

\section{Dr. Matthias Drilling}

Matthias Drilling is Head of the Institute Social Panning, Organisational Change and Urban Development. He studied Geography and finished a Master in Spatial Planning at the Swiss Federal Institute of Technology (ETH) in Zürich. His research and teaching focuses on sustainable urban development and urban democratic action. He is reviewer for the DFG, Swiss National Foundation SNF, German Academic Exchange DAAD and several Ministries and Departments in Switzerland and Germany. He is also head of the neighbourhood research network of the German Geographical Society. 